\title{
Analysis and application of the SRBSDV P9-1 octamer crystal structure for the target of a-amino phosphonate derivatives
}

\author{
Yan Ding ${ }^{1}$, Xiangyang Li ${ }^{1}$, Kai Chen ${ }^{1}$, Guoping Zhang ${ }^{1}$, Liangzhi Luo ${ }^{1}$, Deyu Hu${ }^{1}$ and \\ Baoan Song ${ }^{1}$ \\ ${ }^{1}$ State Key Laboratory Breeding Base of Green Pesticide and Agricultural Bioengineering, Key Laboratory of Green Pesticide \\ and Agricultural Bioengineering, Ministry of Education, Guizhou University, Huaxi District, Guiyang 550025, PR China \\ Correspondence to: Baoan Song, email: basong@gzu.edu.cn \\ Xiangyang Li, email: xyli1@gzu.edu.cn
}

Keywords: targets; SRBSDV P9-1; octamers; bind to; a-amino phosphonate derivatives

Received: October 17, $2017 \quad$ Accepted: December 05, 2017

Published: January 13, 2018

Copyright: Ding et al. This is an open-access article distributed under the terms of the Creative Commons Attribution License 3.0 (CC BY 3.0), which permits unrestricted use, distribution, and reproduction in any medium, provided the original author and source are credited.

\section{ABSTRACT}

Southern rice black-streaked dwarf virus (SRBSDV) P9-1 octameric protein accumulates viroplasms in SRBSDV-infected plant and insect cells, our previous studies found a-amino phosphonate drug-dufulin had a micromole affinity with SRBSDV P9-1. Now we focus our studies on the SRBSDV P9-1 crystal structure and use it as the target for a-amino phosphonate derivatives. The structure of the SRBSDV P9-1 cylindrical octamer was determined to a $2.2 \AA$ resolution using X-ray crystallography, this structure was composed of nine a-helices, nine $\beta$-sheets and a series of interconnecting loops. The structures of all eight subunits were nearly identical, except for some differences in the $\beta$-sheet core. There were six different sites (R20K, V109D, F164T, V123L, C124L and V128T) present between the SRBSDV P9-1 and the previously reported RBSDV P9-1 crystal structure. Fluorescence titration, isothermal calorimetry and microscale thermophoresis experiments showed that a-amino phosphonate derivatives GUFCC-013 and GUFCC-023 bound to SRBSDV P9-1 with micromole binding affinities. These results will provide important help for the further improvement of the lead compound and develop the potential anti-SRBSDV drugs.

\section{INTRODUCTION}

The formation of viroplasms (Vps) is a feature of the genus fijivirus. This formation is intrinsic to viral particle functioning in virus-infected plants and insect cells [1-3]. Southern rice black-streaked dwarf virus (SRBSDV), a newly discovered member of the genus fijivirus [4, 5], causes the devastating southern rice black-streaked dwarf and maize rough dwarf diseases in crops, which lead to severe yield losses in crops in China and Southeast Asia $[6,7]$. The virus is transmitted by an insect vector, the white-backed planthopper sogatella furcifera (Hemiptera: delphacidae) [8]. The genomic segment of SRBSDV is similar to rice black-streaked dwarf virus (RBSDV) and Mal de Río Cuarto virus (MRCV) [9-11].

SRBSDV encodes 13 proteins, including six putative structural proteins (P1, P2, P3, P4, P8, and P10) and seven putative nonstructural proteins (P5-1, P5-2, P6, P7-1, P7-
2, P9-1, and P9-2) [12]. The most important nonstructural protein is P9-1, which is a major constituent of the Vps and shares $78 \%$ amino acid identity with RBSDV P9$1[13]$. In members of the genus fijivirus, P9-1 performs an important function in the early stages of the virus life cycle by forming intracellular Vps which orchestrate virus replication and assembly [14]. In cultured insect vector cells, knockdown of SRBSDV P9-1 expression through RNA interference strongly inhibits Vps formation and viral infection [15]. During infection, SRBSDV P9-1 interacts with P5-1 and P6, formed the Vp matrix in insect cells [12, 16-19].

Nonstructural virus proteins are required for the formation of cytoplasmic structures, and are regarded as key players in viral morphogenesis. In orbiviruses such as bluetongue virus, nonstructural protein NS2 is responsible for recruiting both the core proteins and newly synthesized transcripts [20]. In phytoreoviruses 
such as rice dwarf virus, nonstructural protein Pns12 forms Vp-like structures [21]. In rotaviruses encoded two nonstructural proteins, NSP2 and NSP5 [22], however, only NSP2 contributes to the binding of single-stranded RNA (ss-RNA) [23]. Inmammalian genera of the family reoviridae, $\mu \mathrm{NS}$ is sufficient to form VFs (viral factories) [24], and it recruits $\sigma \mathrm{NS}$ to VFs [27]. The $\mu$ NS protein acts as a scaffold to recruit viral core surface proteins [25], while $\sigma \mathrm{NS}$ binds preferentially to ss-RNA and ssDNA $[26,27]$. In members of the genus fijivirus such as RBSDV, nonstructural protein RBSDV P9-1 is important for the functioning of the relative proteins in Vps during viral morphogenesis [28], RBSDV P9-1 self-associates into aggregate formations and preferentially binds ss-RNA molecules [29, 30]. Given the high homology between SRBSDV P9-1 and RBSDV P9-1 [31], SRBSDV P9-1 could have a similar function, and may also be able to bind small molecules.

In our previous studies, we characterized the binding of dufulin with a dissociation constant of $\sim 3.26$ $-\sim 8.55 \mu \mathrm{M}$ to the SRBSDV P9-1 oligomer based on the results of isothermal calorimetry (ITC) and microscale thermophoresis (MST) [32, 33]. Dufulin, a novel antiviral agent of $\alpha$-amino phosphonate, inhibits the replication of plant viruses [34]. In order to optimize and develop antiSRBSDV compounds with high affinities of SRBSDV P91 , our lab synthesized a series of $\alpha$-amino phosphonate derivatives [35].

Herein we focus our studies on analyzed the crystal structure of SRBSDV P9-1 using X-ray crystallography and investigated the interaction studies of $\alpha$-amino phosphonate derivatives and SRBSDV P9-1 octamer using Fluorescence Titration (FT), ITC and MST. With the purpose of providing important help for the further improvement of the lead compound of $\alpha$-amino phosphonate derivatives, P9-1 structure was used as a target.

\section{RESULTS}

\section{Expression, purification and crystallization of SRBSDV P9-1}

To prepare SRBSDV P9-1 for crystallization, SRBSDV P9-1 genes were overexpressed when the final concentration was increased to $0.7 \mathrm{mM}$ isopropyl$\beta$-D-galactopyranoside (IPTG) and the solution was left overnight at $16^{\circ} \mathrm{C}$. More than $90 \%$ of the $\mathrm{P} 9-1$ protein was eluted. Then, the GST-tagged was cut overnight at $4^{\circ} \mathrm{C}$ by prescission protease, and the dealt proteins were loaded in size exclusion chromatography (SEC) column, in a buffer containing $10 \mathrm{mM}$ Tris- $\mathrm{HCl}$ and $100 \mathrm{mM}$ sodium chloride $\mathrm{pH} 7.5$, the retention time of the SRBSDV P9-1 protein was determined with octameric formation (Supplementary Figure 1) [31]. The final yield from $500 \mathrm{ml}$ of bacterial culture was about $3.5 \mathrm{mg}$ of purified SRBSDV P9-1 protein after using a desalting column. SRBSDV P9-1 crystals were crystallized using hanging-drop vapor diffusion, most crystals of SRBSDV P9-1 with a typical maximal dimension of $0.2 \mathrm{~mm} \times 0.3 \mathrm{~mm}$ within 10 days.

\section{Overall architecture of SRBSDV P9-1}

SRBSDV P9-1 crystals belong to the orthorhombic space group $\mathrm{C} 2221$, with unit cell dimensions $\mathrm{a}=120 \AA$, $\mathrm{b}=152 \AA$ and $\mathrm{c}=146 \AA$ (Supplementary Table 1). The structure was solved by molecular replacement and refined to a resolution of $2.2 \AA$ (PDB accession code: 5EFT). The eight subunits of the asymmetric unit were individually refined by simulated annealing, as indicated by the root mean square deviation (RMSD) between the individual subunits (0.01-0.02 $\AA$ ). The secondary structure of each subunit in the refined atomic model was very similar to that described previously by Akita et al [28], with RMSDs of $\sim 0.6 \AA, \sim 1.6 \AA$ and $\sim 1.6 \AA$ for the carbon-alpha backbone (not including the loop region). The residue of the monomer densities corresponding to fitted coordinates were supplied in Supplementary Figure 2. The wellordered portions had similar secondary structure in all eight subunits in the octamer [28].

The overall structure of SRBSDV P9-1 was similar to the RBSDV P9-1 octamer [28]. The SRBSDV P9-1 octamer was $\sim 83.33 \AA$ in height, $\sim 95.14 \AA$ in width (Figure 1A) and $\sim 119.51 \AA$ in diameter (Figure 1B). The diameter of the axial pore was $39.51 \AA$ at the bottom panel (Figure 1C), and was $18.48 \AA$ at the top panel (Figure 1D).

In the atomic model, the SRBSDV P9-1 monomer was made up of nine $\alpha$-helices, nine $\beta$-sheets and a number of interconnecting loops (Figures 2A and 2B). The eight cylindrical helical subunits (A1, A2, A3, A4, a1, a2, a3 and a4) together form the octameric SRBSDV P9-1 assembly (Figures 2C and 2D). The ordered segments of the A2-, a1-, a2- and A3- chains can be superimposed on each other by a rigid body translation with a RMSD of $0.2 \AA$ for the carbon-alpha atoms (Supplementary Figures 2-4), while the C termini (326-349 amino acids) which were well-ordered in the electron density maps (Supplementary Figures 2C and 2D).

Four interactions among each subunit were clearly visible (A2-A1, A2-A3, A2-a1 and A2-a2). The interactions between A2 and A3 were Asn310 and Ile336 (one bonds); Asn310 and Val335 (one); Arg281 and Ser334 (one); Glu313 and Arg216 (two), with five hydrogen bonds in main chains, the residue densities corresponding to fitted coordinates are supplied in Figure 3A and Supplementary Figure 5, The interactions between $\mathrm{A} 2$ and $\mathrm{A} 1$ were same as the interactions between A2 and A3, with five hydrogen bonds in main chains, the residue densities corresponding to fitted coordinates were supplied in Figure 3B and Supplementary Figure 5, The interactions between A2 and a1 were Asp346 and Asn247 (two); Arg322 and Ser41 (one); Glu16 and Arg325 (one) with four hydrogen bonds in side chains (Figure 3C and 
Supplementary Figure 6). The interactions between A2 and a2 were Gln252 and Gln267 (two); Tyr259 and Gln267 (two); Asp257 and Arg216 (one); Asp262 and Asn258 (one) with six hydrogen bonds in side chains (Figure 3D and Supplementary Figure 7). In the helical region, the electron density map was particularly well ordered. In the sheet region, a poor-quality electron density corresponding to the protein (residues 13-19; 42-49; 113-117; 121129; 162-167; 288-291; 303-306; 319-322) was mapped (Supplementary Figure 8). Therefore, residues
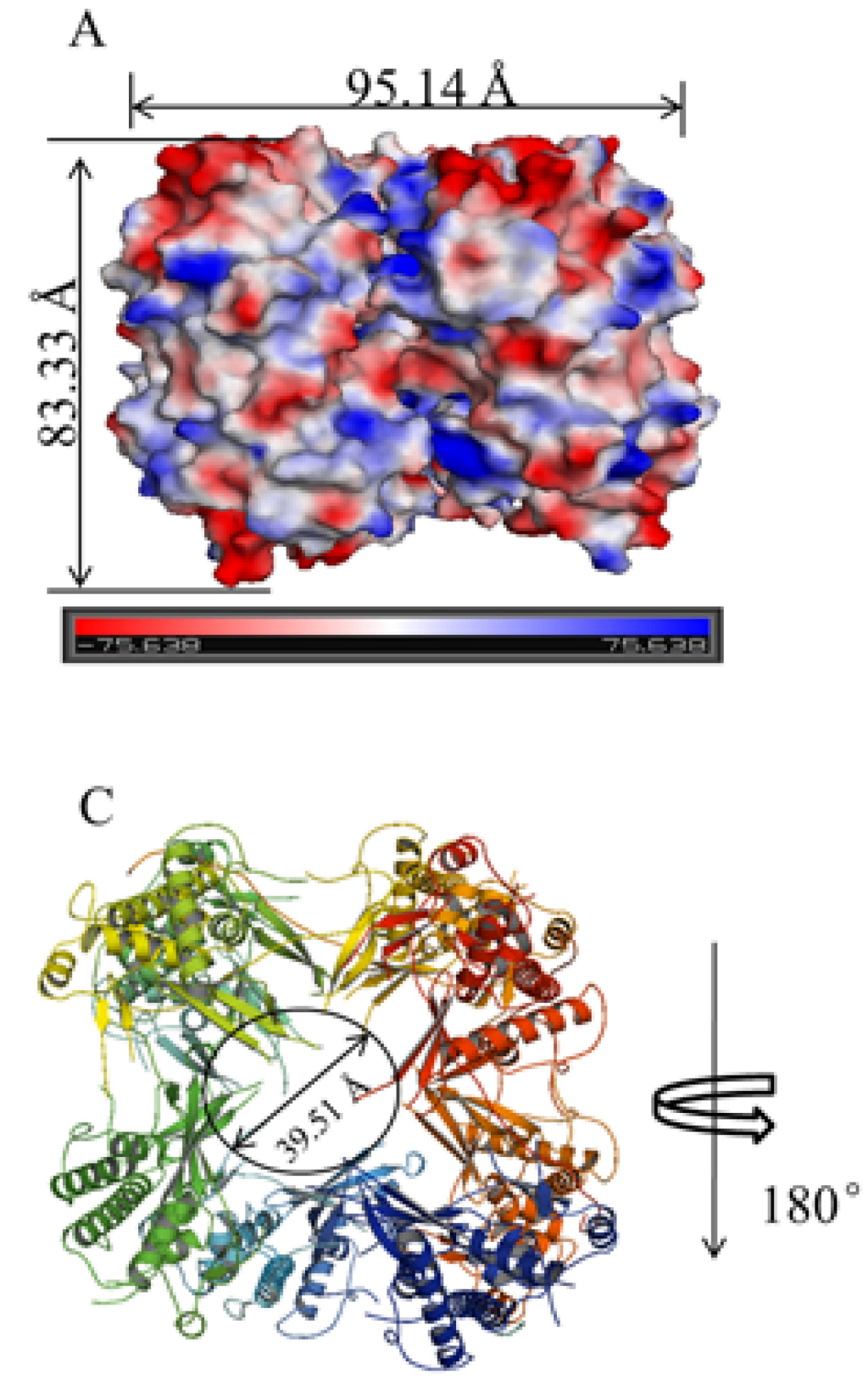

20-41(NDQPTRNTNLSLSQSTENRLS) were absent between the $\beta 1$ and $\beta 2$ atomic model, and residues 128-162 (KTVVESESSTKDQKDDESQKPTSTDSTKNEQEK) were absent in the $\beta 4$ and $\beta 5$ atomic model, and residues 295-301 (LRGAPRQ) were absent in the $\beta 6$ and $\beta 7$ atomic model, and residues 103-106 (LDLA) were absent in the $\alpha 2$ and $\beta 3$ atomic model, and residues $175-180$ (ESEES) were absent in the $\beta 5$ and $\alpha 3$ atomic model, and residues 239-245 (TTVPEKK) were absent in the $\alpha 5$ and $\alpha 6$ atomic model.

B

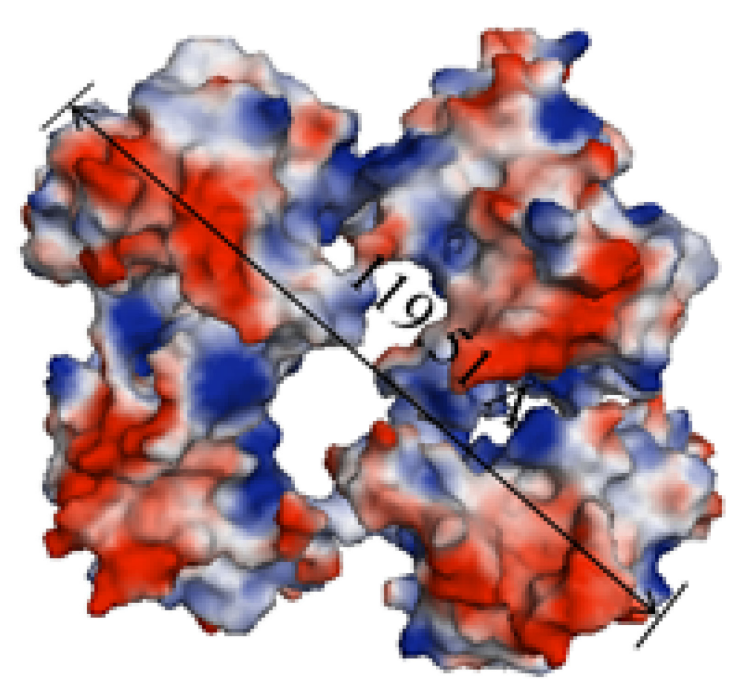

Figure 1: Crystal structure of SRBSDV P9-1 octamer. (A) Electrostatic surface presentation of SRBSDV P9-1 cylinder octamer of $\sim 83.33 \AA$ in height and $\sim 95.14 \AA$ in width. Positively and negatively charged regions were colored blue and red, respectively. The electrostatic surface was calculated in pyMOL. (B) Electrostatic surface presentation of SRBSDV P9-1 octamer of $\sim 119.51 \AA$ in diameter. (C) Own of two P9-1 monomers form dimers via hydrophobic interactions; four P9-1 neighboring dimers form a hollow octamer via carboxy-terminal regions, there was a diameter axial pore with $\sim 39.51 \AA$ at bottom panel. (D) The P9-1 hollow octamer existed a diameter axial pore with $\sim 18.48 \AA$ at top panel, and D was rotated for 180 degrees of C. 


\section{Comparison with the reported RBSDV P9-1 secondary structure}

The secondary structure of SRBSDV P9-1 was consistent with the previously reported structure of RBSDV P9-1, part form the presence of helix in 332-325 aa $(\alpha 9)$ at the $\mathrm{C}$-terminus and five additional $b$-sheets in $13-19$ aa $(\beta 1), 43-49$ aa $(\beta 2), 113-117$ aa $(\beta 3), 121-127$ aa $(\beta 4)$ and $163-168$ aa $(\beta 5)$ (Figure 4$)$ at the $N$-terminus that form a novel $\beta 1-5$ region. The major differences from the previously reported RBSDV P9-1 structure were the manner of subunit assembly and the specific proteinprotein interactions in the major overlap and internal overlap regions. Superposition of the core of the protein backbone carbon-alpha atoms (RMSD of $\sim 1.1 \AA$ ) confirms the similar overall folding octameric structure. The ordered segments of the A- and a-chains can be superimposed on each other by a rigid body translation with a RMSD of $0.2 \AA$ for the carbon-alpha atoms. All helical residue densities corresponded to the fitted coordinates, and the electron density for large polar and charged amino acids and some small polar and charged residues and basic side chains were in clear with the fitted coordinates. A $2 \mathrm{Fo}^{-}$ $F c$ electron density map of the SRBSDV P9-1 octamer contoured at the $1.0 \sigma$ level, and the amino acid sequence numbers are included.

Four obvious interactions among subunits were visible in the SRBSDV P9-1 structure, and these were similar to the four inter-subunit interactions observed in the RBSDV P9-1 structure, although there were a greater number of hydrogen bonds in the SRBSDV P9interactions. The interactions between $\mathrm{A} 2$ and $\mathrm{A} 3$, with five hydrogen bonds in main chains (Figure $3 \mathrm{~A}$ ), the interactions between $\mathrm{A} 2$ and $\mathrm{A} 1$, with five hydrogen bonds in main chains (Figure 3B), the interactions between A2 and a1, with four hydrogen bonds in side chains (Figure $3 \mathrm{C}$ ), the interactions between $\mathrm{A} 2$ and a2, with six hydrogen bonds in side chains (Figure 3D). In RBSDV

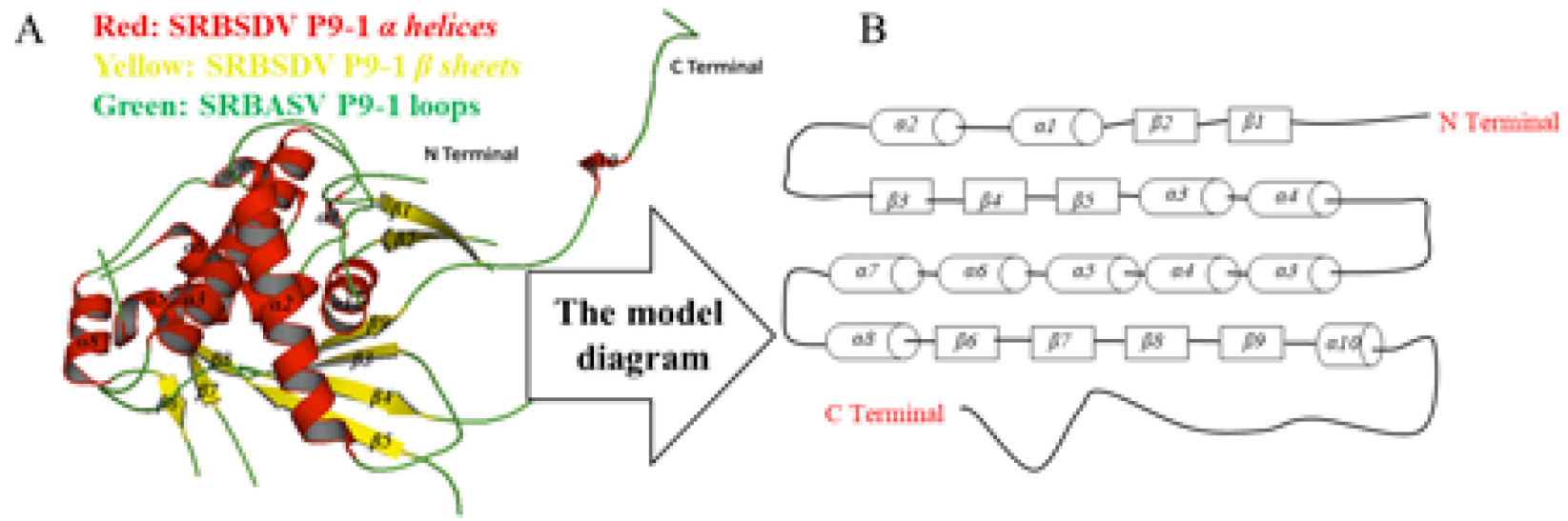

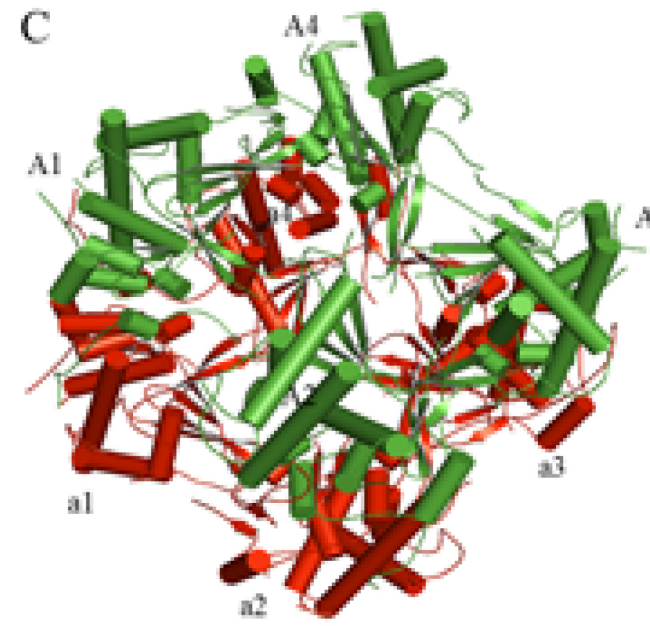

Green: $\mathrm{A1}, \mathrm{Az}_{4} \mathrm{A3}_{4} \mathrm{~A} 4$ subunits Red: a1,a2, a3, ala subunits

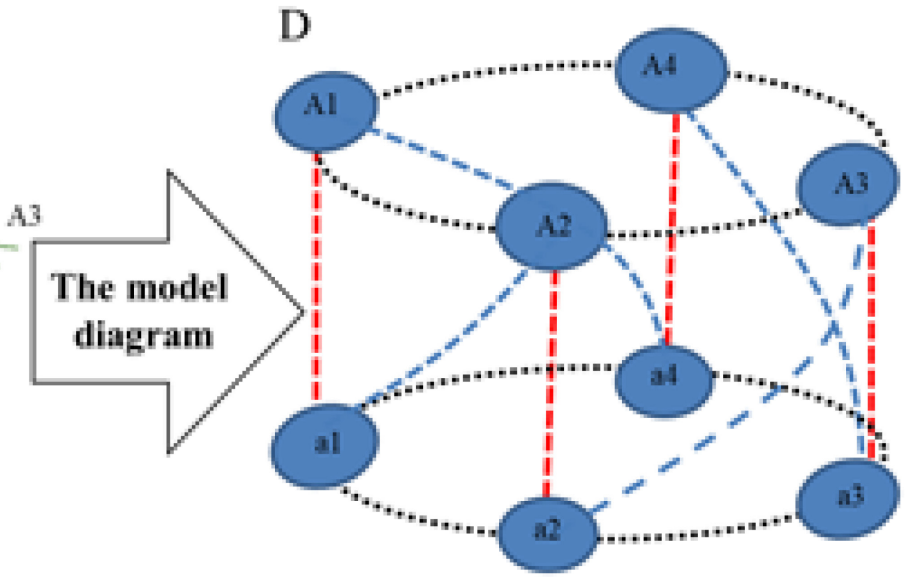

Interaction ----- bonds

Figure 2: A full object model diagram of SRBSDV P9-1 monomer and octamer. (A) SRBSDV P9-1 monomer was made up of nine $\alpha$ helices (red), nine $\beta$ sheets (yellow) and a series of connective loops (green). (B) A full object model diagram of SRBSDV P9-1 monomer. (C) The octameric structure of SRBSDV P9-1 in cylindrical helices, SRBSDV P9-1 octameric structure contains eight monomers, A1 (green), A2 (green), A3 (green), A4 (green), a1 (red), a2 (red), a3 (red) and a4 (red). (D) A full object model diagram of SRBSDV P9-1 octamer, 16 interactions between subunits were indicated by the cyan, red and black dashed lines, the residues are shown according to SRBSDV P9-1 sequence. 
P9-1, there were also three interactions between one monomer and another, but there were less hydrogen bonds in this three interactions, the interactions between $\mathrm{A} 2$ and A3, with only two same hydrogen bonds in main chains, Asn310 and Ile336; Glu313 and Asn33, the interactions between $\mathrm{A} 2$ and a1, with four different hydrogen bonds inside chains, Lys344 and Asn247; Leu343 and Asn247; Lys201 and Ser341; Leu342 and His77, the interactions between A2 and a2, with only three hydrogen bonds (two different, one same) in inside chains, Glu221 and Arg216; Asn258 and Arg216; Asp262 and Asn258 (same).

Superposition of SRBSDV P9-1 and RBSDV P9-1 (PDB code $3 \mathrm{VJJ}$ ) revealed differences in the conformation of main-chain and side-chain atoms (Figure 5A). Compared with RBSDV P9-1 (PDB code 3VJJ), SRBSDV P9-1 residues in the $\beta$-sheet regions (residues 13-20, 42-48,

A

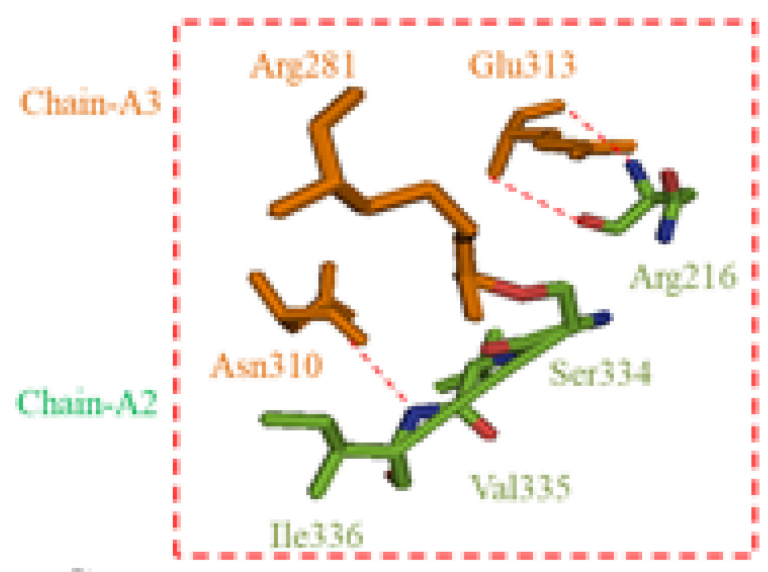

C

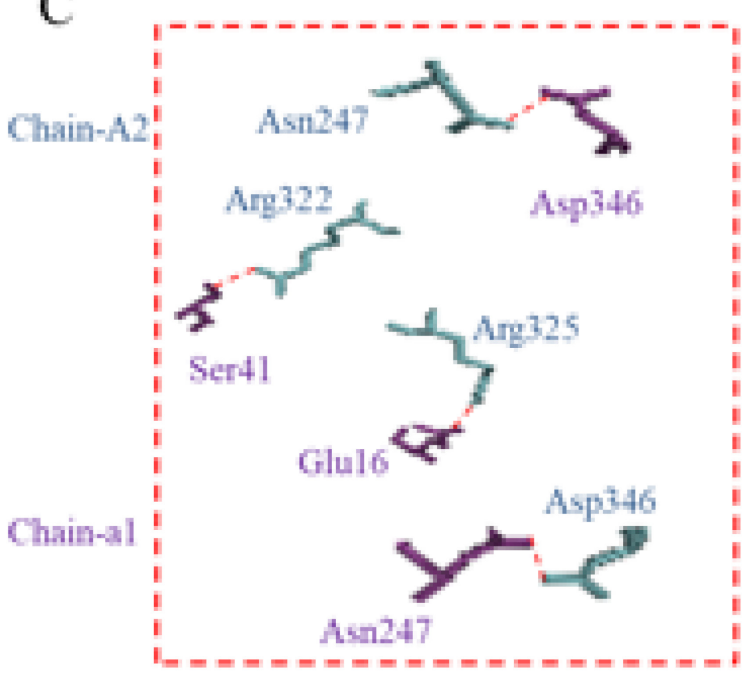

$108-110,162-168,122-129)$ had a higher atomic $B$ factor, indicating a greater degree of disorder. In the SRBSDV P9-1 structure determined in this work, these residues were stabilized by protein-protein hydrogen bonding interactions with the adjacent subunit (Figure 5B).

Six major differences were present in the $\beta$-sheet regions of RBSDV P9-1 and SRBSDV P9-1, suggesting the charged and polar residues (K20R, D109V, T164F, L123V, L124C, T128V) in these positions was involved in binding small molecules or nucleic acids, and was negatively or positively charged as appropriate for forming the corresponding complex. In addition, in the pore of the structure of the SRBSDV P9-1 octamer, the longer $\beta$-sheet structures in the P9-1 cylindrical octamer core were disordered (Figure 2C). This may be due to the fact that the core structure forms five bundles of the charged

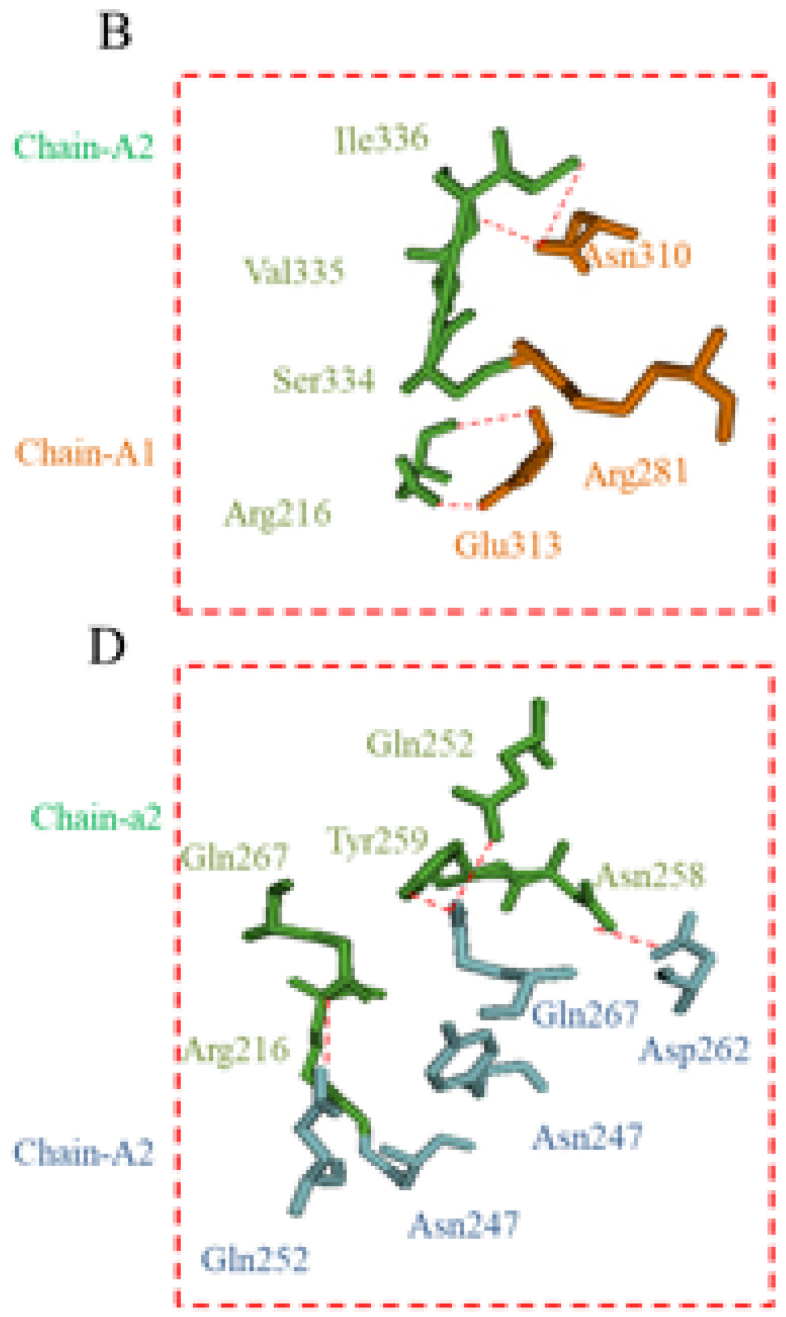

Figure 3: The interactions involved in subunits of SRBSDV P9-1 octamer. (A) The interactions between A2 and A3, with five hydrogen bonds in main chains in a partial enlarged details, Asn310 and Ile336 (one bonds); Asn310 and Val335 (one bonds); Arg281 and Ser334 (one bonds); Glu313 and Arg216 (two bonds). (B) The interactions between A2 and A1, with five hydrogen bonds in main chains with a partial enlarged details, Asn310 and Ile336 (one bonds); Asn310 and Val335 (one bonds); Arg281 and Ser334 (one bonds); Glu313 and Arg216 (two bonds). (C) The interactions between A2 and a1, with four hydrogen bonds in side chains with a partial enlarged details, Asp346 and Asn247 (two bonds); Arg322 and Ser41 (one bonds); Glu16 and Arg325 (one bonds). (D) The interactions between A2 and a2, with six hydrogen bonds in side chains with a partial enlarged details, Gln252 and Gln267 (two bonds); Tyr259 and Gln267 (two bonds); Asp257 and Arg216 (one bonds); Asp262 and Asn258 (one bonds). 
and polar amino acid residues (KIEELTIK, TKKIPLLD, YDR, TKTEMS and LLLEYTL) (Figure 6).

\section{The affinities of SRBSDV P9-1 octamers and $\alpha$-amino phosphonate derivatives}

To investigate the binding studies of $\alpha$-amino phosphonate derivatives and the P9-1 proteins, we focus our studies on the interactions between $\operatorname{six} \alpha$-amino phosphonate derivatives and the P9-1 proteins using FT methods, the constants of all six $\alpha$-amino phosphonate derivatives binding to the $\mathrm{P} 9-1$ proteins were listed in Supplementary Table 2, the quenching constants for the interaction obtained by the Stern-Volmer method were listed. The binding constant between six $\alpha$-amino phosphonate derivatives and the $\mathrm{P} 9-1$ proteins can be calculated by employing the Lineweaver-Burk equation $\lg \left(\mathrm{F}_{0}-\mathrm{F}\right) / \mathrm{F}=\lg K_{\mathrm{a}}+\mathrm{n} \lg [\mathrm{Q}]$. The curves of $1 /\left(\mathrm{F}_{0}-\mathrm{F}\right)$ versus $1 /[\mathrm{Q}]$ were linear. As a rule, for dynamic quenching, the maximum scatter collision-quenching constant of various quenchers is $2.0 \times 10^{10} \mathrm{~L} \cdot \mathrm{mol}^{-1} \cdot \mathrm{S}^{-1}[36]$.
The rate constants of the protein quenching procedure initiated by six $\alpha$-amino phosphonate derivatives were greater than $2.0 \times 10^{10} \mathrm{~L} \cdot \mathrm{mol}^{-1} \cdot \mathrm{S}^{-1}$, which means that the quenching process was static (Supplementary Table $2)$. The six $\alpha$-amino phosphonate derivatives bound to the P9-1 proteins with different binding affinities, which was in the order of $K_{(\mathrm{G} 23-\mathrm{P} 9)}$ (4-chlorophenyl) $>K_{(\mathrm{G} 13-\mathrm{P} 9)}$ (phenyl) $>K_{\text {(G35-P9) }}$ (2-nitrophenzyl) $>K_{(\mathrm{G} 39-\mathrm{P} 9)}$ (thiphene 2-yl) $>K_{(\mathrm{G} 31-\mathrm{P} 9)}$ (4-methylphenyl) $>K_{(\mathrm{G} 5-\mathrm{P} 9)}$ (2-fluorophenyl), show differences, it was undeniable that GUFCC-013 and GUFCC-023 bound to the P9-1 proteins with good affinities. As shown in Figures 7A and $7 \mathrm{~B}$, the fluorescence intensity of the $\mathrm{P} 9-1$ proteins was decreased with increasing of GUFCC-013 and GUFCC-023 concentration, and the fluorescence intensity of GUFCC-013 and GUFCC-023 was quenched steadily with the increasing concentration of the GUFCC-013 and GUFCC-023.

Two advanced techniques, ITC and MST, were utilized in the experiments allowing us to prove the interaction results by FT in vitro. The ITC responses

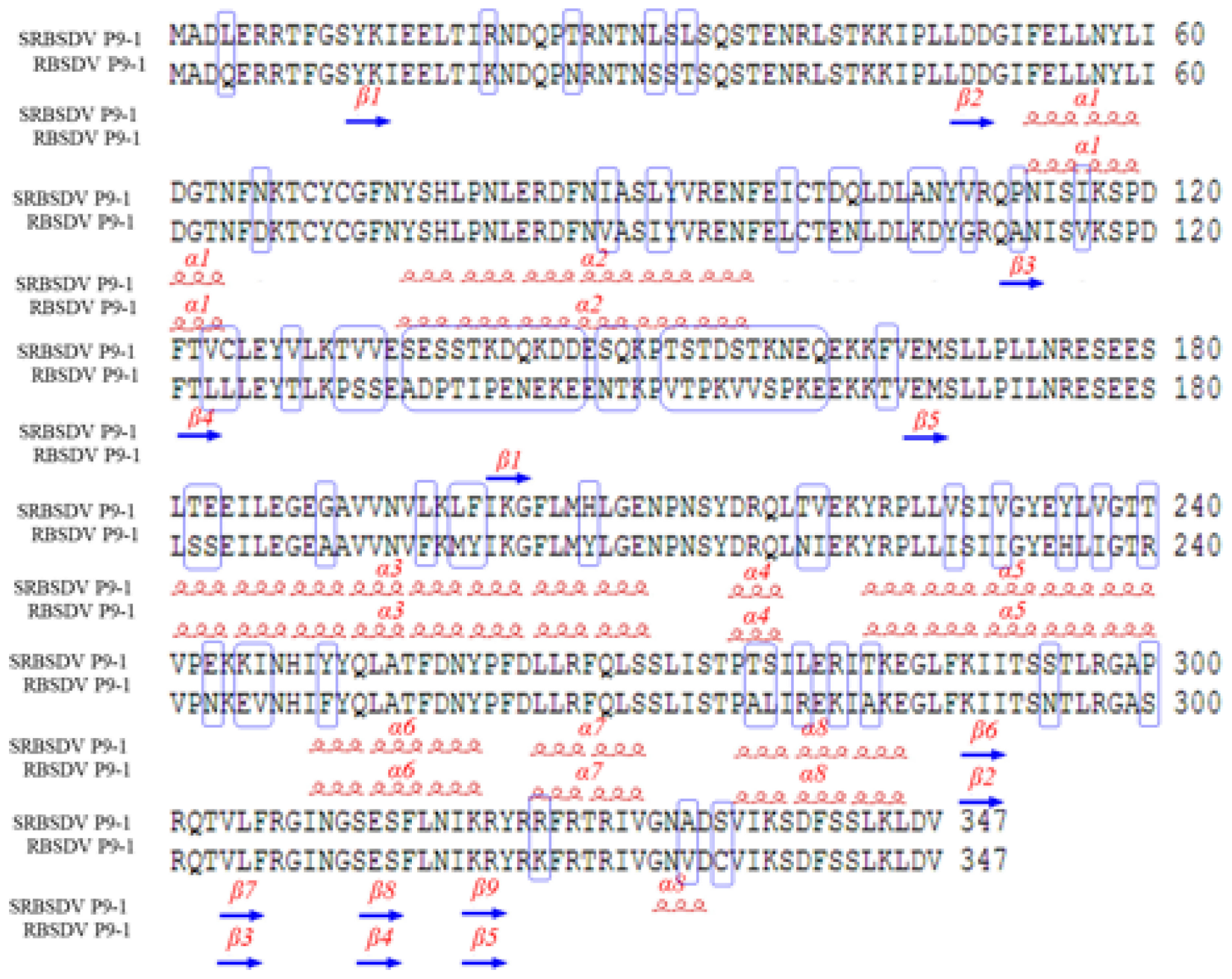

Figure 4: Alignment of the amino acid sequences of SRBSDV P9-1 and RBSDV P9-1. Secondary structural elements are indicated schematically under the sequences, generated by EMBL-EBI sequence alignment programs server, and indicated as difference residues (blue box) or spirals ( $\alpha$ helices) or arrows ( $\beta$ sheets). 
recorded during titration of the $\mathrm{P} 9-1$ proteins with GUFCC-013 and GUFCC-023 were shown in Figures 7C and 7D. Binding studies for interactions of the P9-1 proteins with GUFCC-013 and GUFCC-023 were listed in Supplementary Table 3. Obviously, the GUFCC013-P9-1 and GUFCC-023-P9-1 with a $K_{\mathrm{a}}$ of $9.12 \times 10^{4}$ and $1.41 \times 10^{5}$ exhibited higher binding affinities, showed similar affinities with dufulin [32], it was consistent with the results of fluorescence. The results showed that the GUFCC-013 and GUFCC-023 bound to the P9-1 proteins with a dissociation constants $\left(K_{\mathrm{d}}\right)$ of $6.01\left(K_{\mathrm{a}}=\right.$ $\left.1.66 \times 10^{5}\right)$ and $2.88\left(K_{\mathrm{a}}=3.47 \times 10^{5}\right) \mu \mathrm{M}$, respectively (Figures $7 \mathrm{E}$ and $7 \mathrm{~F}$ ), The binding datas determined from MST experiments were listed in Supplementary Table 4. Determined $K_{\mathrm{d}}$ obtained in ITC and MST experiments were corresponding to data obtained by means of FT. All the results indicated that $\alpha$-amino phosphonate derivatives containing 4-chlorophenyl group and phenyl group will provide important help for the further improvement of the lead compound and develop to the potential anti-SRBSDV drugs.
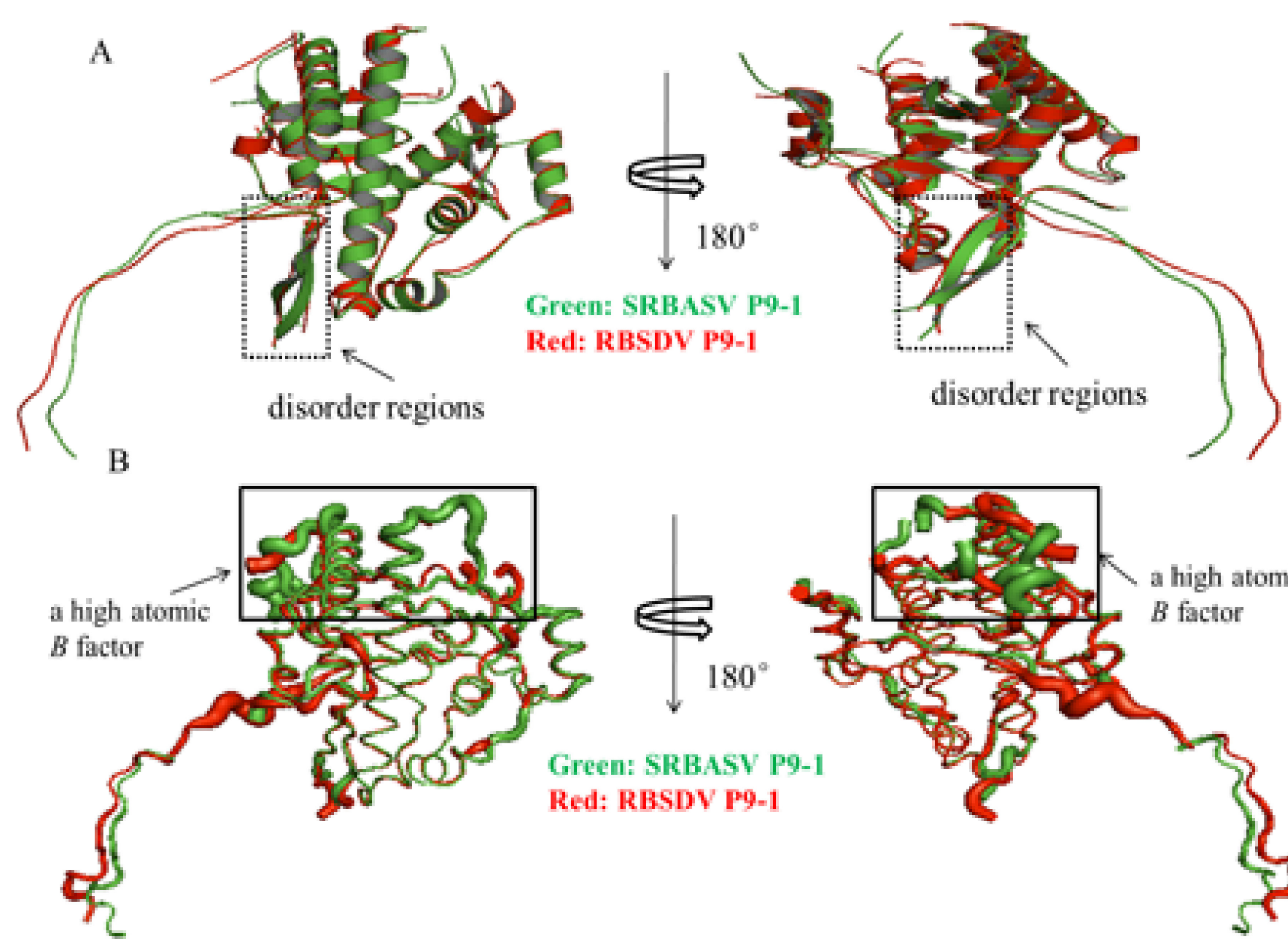

Green: SRBASV P9-1

Red: RBSDV P9-1
Molecular docking results showed that the P9-1 interacts with GUFCC-023 through Arg237 (Supplementary Figure 9), and then we expressed the mutated P9-1 (R327A) protein by site mutation. MST results showed that the GUFCC-023 bound to the mutated P9-1 (R327A) with a $K_{d}$ of $10.97 \mu \mathrm{M}\left(n=1, K_{d}\right.$ confidence $=2.77)$, The binding affinities were significant differences between the mutated P9-1 (R327A) and wild type P9-1 (2.88 $\mu \mathrm{M}$ in Supplementary Table 4). Furthermore, the Arg327 was the key residue to form the dimmer of P9-1 protein. The results indicated that the Arg327 was key residue for GUFCC-023 binding.

\section{DISCUSSION}

The P9-1 expressed without a tag was capable of forming high-quality crystals suitable for X-ray diffraction studies. When P9-1 was expressed with an N-terminal 6 $\times$ His tag or truncated at the $\mathrm{C}$ or $\mathrm{N}$ terminus, crystals did not form. The reason for these was remained to be determined. It was possible that these proteins formed a 
heterogeneous mixture of monomers, dimers, tetramers, and octamers that were less amenable to forming a wellordered crystal lattice, except deleted tags.

In the crystal structure of SRBSDV P9-1 determined in the present study, 16 main interactions among subunits form an octamer. A number of polar and charged amino acids lie in the core of SRBSDV P9-1 octamer formed from the $\beta$-sheet regions. The electron density map indicated that some residues in this region were disordered in the SRBSDV P9-1 octamer core. Interestingly, The 2.2 $\AA$ structure was a higher resolution than that reported for the homologous RBSDV P9-1, and a greater number of polar and charged residues and interactions were visible in the core of the SRBSDV P9-1 structure compared with RBSDV P9-1. Furthermore, the conformation and overall structure of SRBSDV P9-1 appeared to be more complex than that of RBSDV P9-1.
These polar and charged residues in the SRBSDV P9-1 octamer core were likely to adopt an ordered structure when it bound to P9-1 DNA segments (we will report in other article), and keep the activity of the P9-1 octamers. In our previous reported, we found $\alpha$-amino phosphonate compound - dufulin had a micromole affinity with SRBSDV P9-1, and were corresponding to the activity data in vivo, so $\alpha$-amino phosphonate compound was a good ligand target for P9-1 octamers.

Then we focus our studies on the crystal structure of the P9- 1 as the target for $\alpha$-amino phosphonate derivatives. Using FT, ITC and MST methods, we screened two $\alpha$-amino phosphonate derivatives GUFCC-013 (containing 4-chlorophenyl group) and GUFCC-023 (containing phenyl group) which exhibited high binding affinities. This finding implies that it is possible to develop $\alpha$-amino phosphonate derivatives containing 4-chlorophenyl and
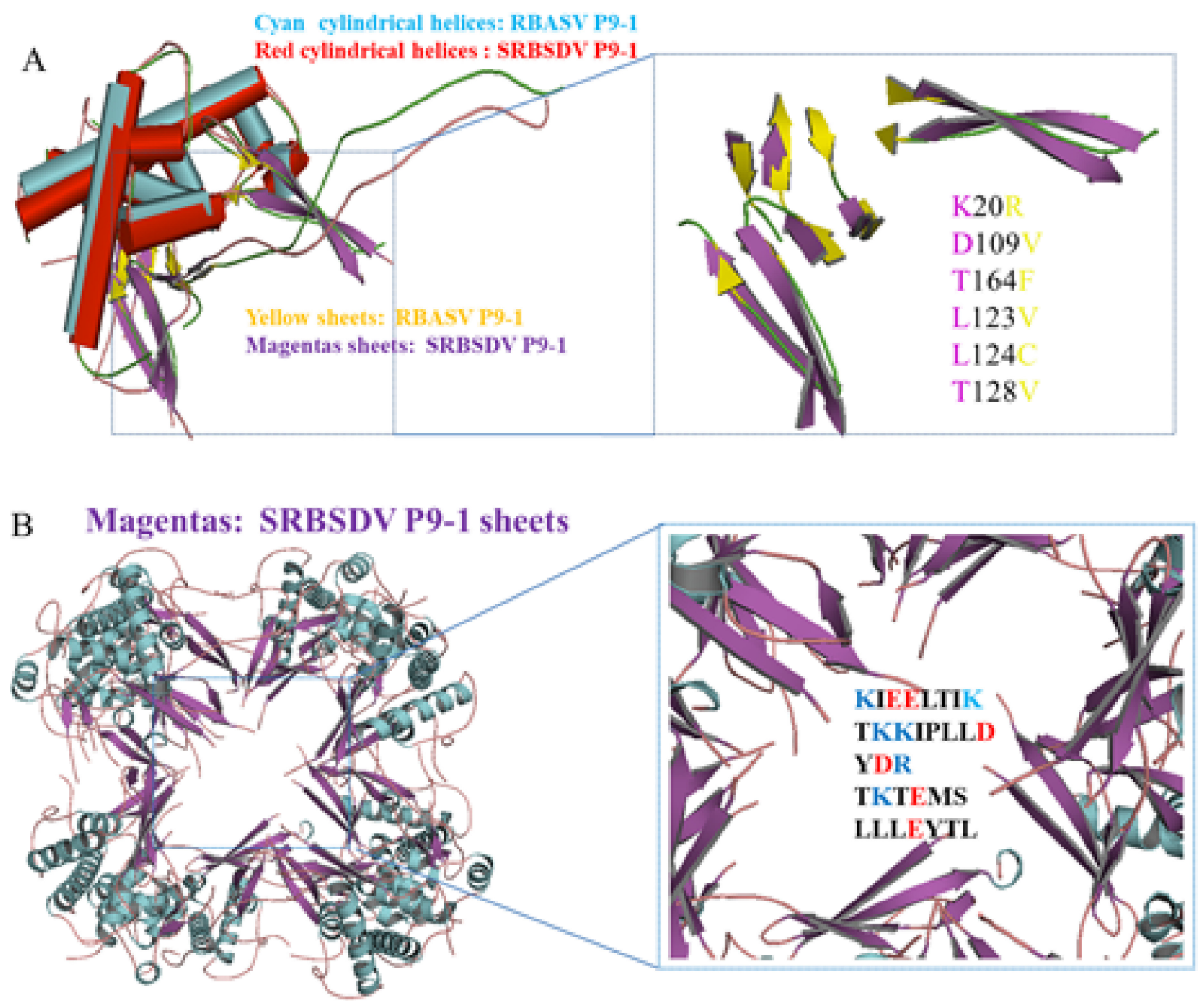

Figure 6: The internal pore of octamer structure of SRBSDV P9-1. (A) Superposition of monomers between the a -chain of SRBSDV P9-1 and RBSDV P9-1 (PDB code 3VJJ). In superposition structure of SRBSDV P9-1 sheets, six mutagenesis were found, K20R, D109V, T164F, L123V, L124C, T128V. (B) In SRBSDV P9-1 octamer structures, polar and charged resides (KIEELTIK, TKKIPLLD, YDR, TKTEMS and LLLEYTL) in the octamer pore. 
phenyl groups into the potential anti-SRBSDV drugs. The broad implications of this finding await further investigation of the action of mechanism of GUFCC-013 and GUFCC-023 and the application of the field experiments.

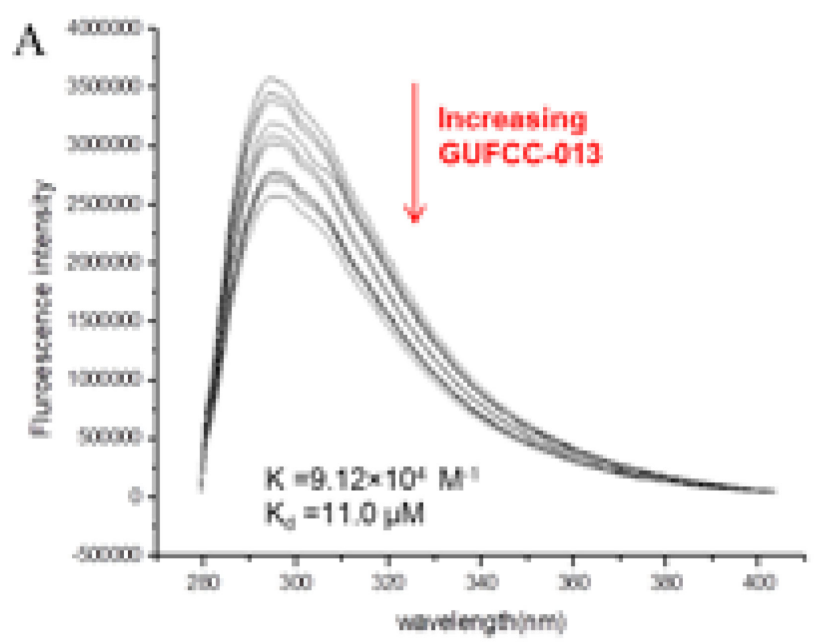

C

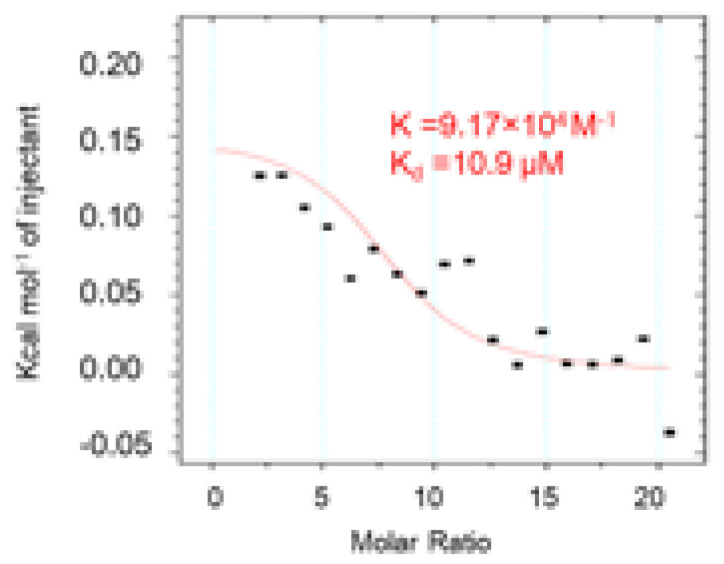

E

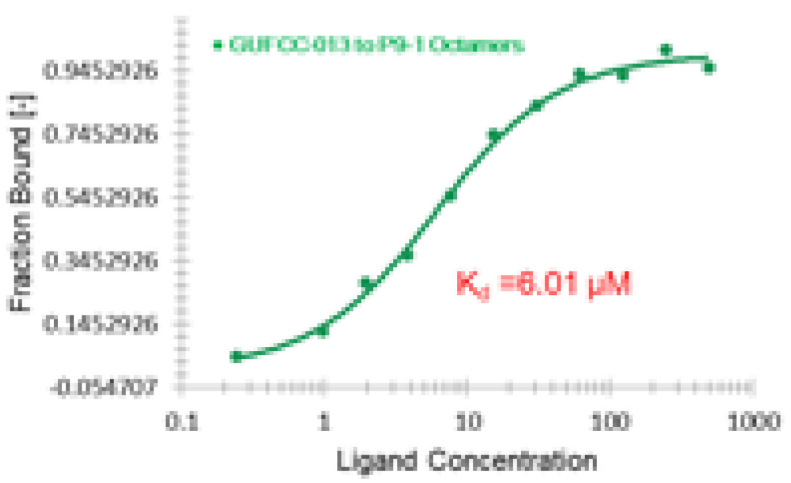

In summary, the results presented here reveal that the high resolution crystal structure of the SRBSDV P9-1 octamer was analyzed and applied it as the target of $\alpha$-amino phosphonate derivatives. In addition, GUFCC-013 and GUFCC-023 was screened with high

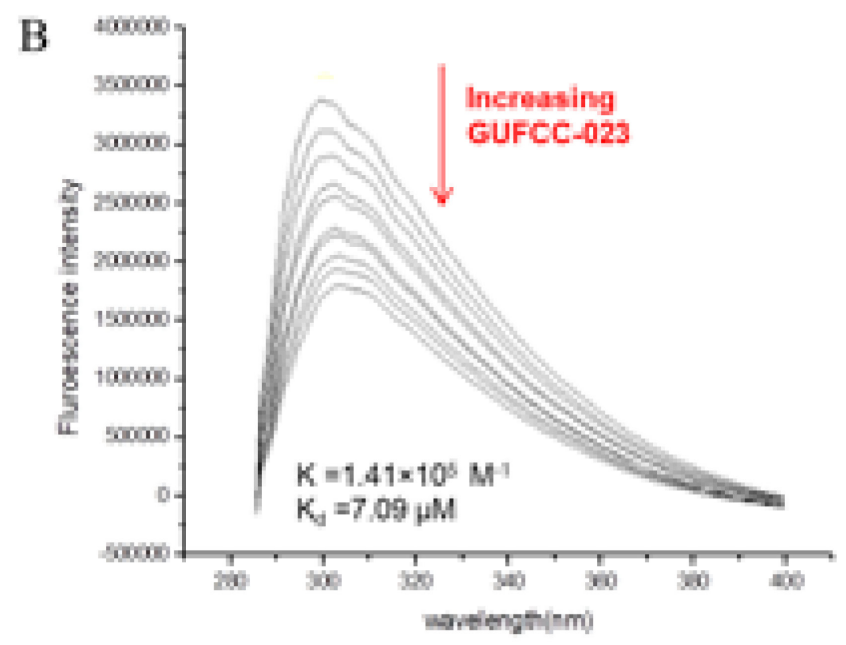

D

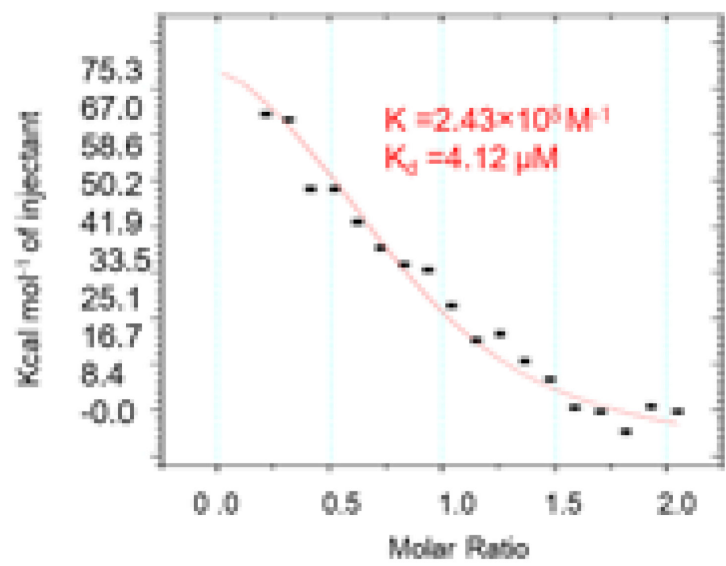

$\mathrm{F}$

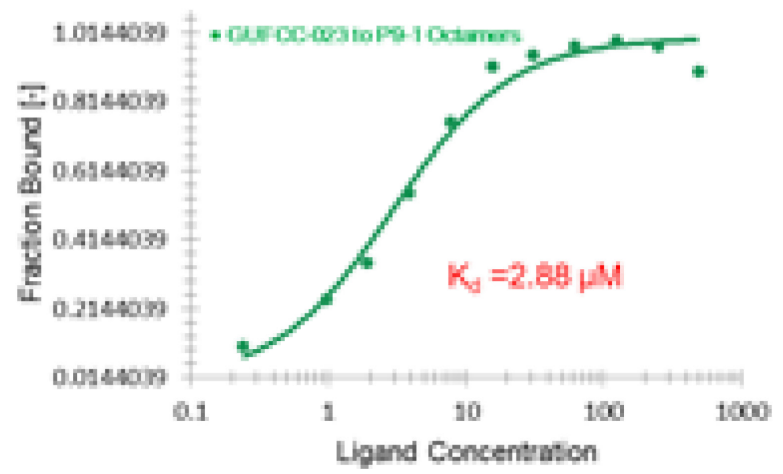

Figure 7: Binding affinities of GUFCC-013 and GUFCC-023 to P9-1 proteins. (A) Fluorescence emission spectra of P9-1 proteins in the presence of increasing GUFCC-013, the results showed that one P9-1 combined one GUFCC-023 with a dissociation constant $\left(K_{\mathrm{d}}\right)$ of $11 \mathrm{nM}$, and the corresponding Ka was $9.12 \times 10^{4} \mathrm{M}^{-1}$. (B) Fluorescence emission spectra of P9-1 proteins in the presence of increasing GUFCC-023, the results showed that one P9-1 combined one GUFCC-023 with a Kd of 7.09 nM, and the corresponding Ka was $1.41 \times 10^{5} \mathrm{M}^{-1}$. (C) ITC results showed that one P9-1 combined one GUFCC-013 with a $K \mathrm{~d}$ of $10.9 \mathrm{nM}$, and the corresponding Ka was 9.17 $\times 10^{4} \mathrm{M}^{-1}$. (D) ITC results showed that one P9-1 combined one GUFCC-023 with a Kd of $4.12 \mathrm{nM}$, and the corresponding Ka was $2.43 \times$ $10^{5} \mathrm{M}^{-1}$. (E) MST results showed that one P9-1 combined one GUFCC-023 with a Kd of $6.01 \mathrm{nM}$. (F) MST results showed that one P9-1 combined one GUFCC-023 with a $K \mathrm{~d}$ of $2.88 \mathrm{nM}$. 
binding affinities to P9-1 octamer, and will develop into the potential anti-SRBSDV drugs.

\section{MATERIALS AND METHODS}

\section{Materials}

GUFCC-005, GUFCC-013, GUFCC-023, GUFCC-031, GUFCC-035 and GUFCC-039 were synthesized in our lab (Supplementary Table 5).

\section{The procedure for recombinant P9-1}

Rice plants infected with SRBSDV were gathered from Guizhou province, China. The SRBSDV total RNA was extracted using the trizol reagent method, and then a spectrophotometer was used to detect trace amounts of nucleic acid. The cDNA synthesis methods were described in a previous report [31].

SRBSDV genomic RNAs were isolated according to previous published methods [31] and were reverse transcribed in the presence of a $9 \mathrm{nt}$ random primer with superscript reverse transcriptase (Invitrogen, USA) according to the manufacturer's instructions. PCR amplification was carried out using iCycler (BioRad, USA) under the following conditions: $94^{\circ} \mathrm{C}$ for $3 \mathrm{~min} ; 20$ cycles at $94^{\circ} \mathrm{C}$ for $50 \mathrm{~s}, 65^{\circ} \mathrm{C}$ for $50 \mathrm{~s}$, and $72^{\circ} \mathrm{C}$ for $50 \mathrm{~s}$, then was followed by 25 cycles at $94^{\circ} \mathrm{C}$ for $50 \mathrm{~s}, 55^{\circ} \mathrm{C}$ for $50 \mathrm{~s}$, and $72^{\circ} \mathrm{C}$ for $50 \mathrm{~s}$, with a final incubation time of $10 \mathrm{~min}$ at $72^{\circ} \mathrm{C}$. The reaction was performed in a $50 \mu \mathrm{L}$ solution containing $400 \mathrm{ng}$ cDNA, $4.0 \mathrm{mM} \mathrm{MgCl}, 1 \mathrm{mM}$ dNTP, $0.8 \mu \mathrm{M}$ of each primer and $2.5 \mathrm{U}$ Taq polymerase (TaKaRa, Japan). The complete P9-1 gene sequence (GenBank accession no. AEB40349) for SRBSDV was used to design primers containing BamHI restriction site in the forward primer (CGGGATCCATGGCAGACCTAGAGCGTA) and EcoRI site in the reverse primer (CCCTCGAGTCAAACGTCCAATTTAAGTGAAG).

The full-length P9-1 gene was digested with BamHI and EcoRI and then inserted into the vector pGEX-6P-1 (Novagen, USA) cut with the same enzymes, resulting in the prokaryotic expression plasmid pGEX-6P-1-P9-1. The sequence of P9-1 was confirmed by DNA sequencing in Shanghai Sangon Company, China. Sequence analysis showed that SRBSDV P9-1 contained 1044 nts and shared a 99\% nucleotide identity with other published SRBSDV isolate sequences in the National Center of Biotechnology Information (NCBI) (GenBank accession no. KJ476858).

The expression vector, pGEX-6P-1-P9-1, containing the full-length P9-1 gene, was designed and used to transform Escherichia coli strain BL21(DE3)RIL (Novagen, USA). A freshly transformed overnight culture of Escherichia coli strain BL21(DE3)RIL containing the plasmid pGEX-6P-1-P9-1 was transferred to $1 \mathrm{~L}$ Luria broth. The cells were grown at $37^{\circ} \mathrm{C}$ in Luria-Bertani medium supplemented with $100 \mu \mathrm{g} / \mathrm{ml}$ Ampicillin, and with an $\mathrm{OD}_{600}$ of 0.65 . The cells were shaken at 200 rpm. Then protein expression was induced with 0.7 mM IPTG at $16^{\circ} \mathrm{C}$ overnight. The cells were harvested by centrifugation and then stored at $-80^{\circ} \mathrm{C}$. When analyzed, the cells were resuspended in lysis buffer $(20$ $\mathrm{mM}$ Tris- $\mathrm{HCl}, 500 \mathrm{mM} \mathrm{NaCl}, 30 \mathrm{mM}$ imidazole, $5 \mathrm{mM}$ $\beta$-mercaptoethanol and 5\% glycerol, $\mathrm{pH} 7.5$ ) and then lysed at $4{ }^{\circ} \mathrm{C}$ by sonication. The lysate was clarified by centrifugation at $12,000 \mathrm{~g}$ for $30 \mathrm{~min}$ at $4^{\circ} \mathrm{C}$, the soluble supernatants were loaded onto a $5 \mathrm{ml}$ Ni-NTA column (GE Healthcare, USA), and the protein was eluted with a linear gradient of 30-350 mM imidazole $(\mathrm{pH} 7.5)$. The crude protein was performed at $4{ }^{\circ} \mathrm{C}$ using a desalting column (GE Healthcare, USA) attached to an AKTA purifier protein liquid chromatography system (GE Healthcare, USA), and the fractions containing target protein with His- and GST-tags were pooled, concentrated to a suitable concentration by ultrafiltration ( $10 \mathrm{kDa}$ cut-off), and the GST-tag was digested off by prescission protease at $4^{\circ} \mathrm{C}(1$ $\mathrm{mg}$ prescission protease with $100 \mathrm{mg}$ GST-tagged fusion protein). The dealt protein concentration was determined using a Genequant 100 (GE Healthcare, USA), and stored at $-80^{\circ} \mathrm{C}$ until further analysis.

SEC was performed at room temperature using a calibrated superdex 200 10/300 GL column (GE Healthcare, USA) attached to an AKTA purifier fast protein liquid chromatography system (GE Healthcare, USA) [37]. The column was equilibrated with a solution containing $10 \mathrm{mM}$ Tris- $\mathrm{HCl}$ and $100 \mathrm{mM}$ sodium chloride solution ( $\mathrm{pH}$ 7.5). The molecular mass standards (BioRad) was used including thyroglobulin $(669 \mathrm{kDa})$, ferritin $(440 \mathrm{kDa})$, BSA $(67 \mathrm{kDa}), \beta$-lactoglobulin $(35 \mathrm{kDa})$, ribonuclease A $(13.7 \mathrm{kDa})$, cytochrome $(13.6 \mathrm{kDa})$, aprotinin $(6.51 \mathrm{kDa})$, and vitamin B12 $(1.36 \mathrm{kDa})$. The protein was monitored by measuring absorbance at a wavelength of $280 \mathrm{~nm}$.

\section{Crystallization and Structure Determination of SRBSDV P9-1}

Crystallization was performed at $20^{\circ} \mathrm{C}$ by using the hanging-drop vapor diffusion method. SRBSDV P9-1 protein was concentrated to $3.5 \mathrm{mg} / \mathrm{mL}$ in a buffer containing $20 \mathrm{mM}$ Tris- $\mathrm{HCl}, \mathrm{pH} 7.5,300 \mathrm{mM} \mathrm{NaCl}$, and $1 \mathrm{mM}$ DTT, and then crystallization conditions were carefully screened [38]. Briefly, $1 \mu \mathrm{L}$ protein solution was mixed with $1 \mu \mathrm{L}$ reservoir solution $(100 \mathrm{mM}$ Trimethylamine N-oxide dihydrate, $100 \mathrm{mM}$ Tris- $\mathrm{HCl}$, $\mathrm{pH} 7.5,16 \% \mathrm{w} / \mathrm{v}$ Polyethylene glycol monomethyl ether 3000 ) and equilibrated against $0.6 \mathrm{~mL}$ reservoir solution. The micro-crystals were grown for 10 days and collected and deposited with a seeding tool (Hampton Research, USA) [38]. Many SRBSDV P9-1 crystals have been crystallized using hanging-drop vapor diffusion within 10 days. High-quality crystals of SRBSDV P9-1 were 
mounted and flash-frozen in liquid nitrogen following cryo-protection with reservoir solution containing an additional $25 \%$ (w/v) Polyethylene glycol monomethyl ether 3000 [38].

Diffraction data were collected at the Shanghai Synchrotron Radiation Facility (SSRF) beamline 17U. All X-ray data were processed using the HKL2000 program [39] and converted to structure factors within the CCP4 program [40]. A typical octahedral-shaped crystal belongs to the space group C2221. The structure was solved by molecular replacement in Phaser [41] using the published RBSDV P9-1 monomer as a search model (PDB code 3VJJ) [28]. The SRBSDV P9-1 model was manually built in COOT [42], and computational refinement was conducted with the program REFMAC5 [43] in the CCP4 suite. Molecular graphic figures were prepared in PyMOL [44], the eight subunits of the asymmetrical unit were refined individually using simulated annealing. There were no departures from the noncrystallographic symmetry found during this procedure of refinement, as indicated by the RMSD between the individual subunits $(0.01-0.02 \AA)$ [45].

The homology of the complete protein sequences SRBSDV P9-1 and RBSDV P9-1 (UniProtKB accession no. Q913E4) was analyzed using the EMBL-EBI sequence alignment programs server (http://www.ebi.ac.uk/Tools/ msa/clustalw2/). The secondary structures of SRBSDV P9-1 were alignment based on their secondary amino acid sequences using the SRBSDV P9-1 X-Ray crystal structure and the RBSDV P9-1 X-Ray crystal structure (PDB code: 3VJJ). The SRBSDV P9-1 3D structure was generated by pyMOL (http://www.pymol.org/).

\section{Interaction studies between NNM and TMV CP}

All fluorescence measurements were made on FluoroMax $^{\circledR}-4$ and FluoroMax ${ }^{\circledR}-4 \mathrm{P}$ (Horiba Scientific, France). The excitation wavelength was $275 \mathrm{~nm}$ while the emission spectra were recorded from $280 \mathrm{~nm}$ to $400 \mathrm{~nm}$. Both the excitation and emission slit widths were set at 5 $\mathrm{nm}$. The concentration of P9-1 proteins for each run was fixed at $10 \mu \mathrm{M}$, the concentration of $\alpha$-amino phosphonate derivatives, respectively $0,2,4,6,8,10,12,14,16$ and $18 \mu \mathrm{M}$. The decrease in fluorescence intensity at the highest peak was analyzed according to the Stern-Volmer equation [46]: $\mathrm{F}_{0} / \mathrm{F}=1+K_{\mathrm{q}} \tau_{0}[\mathrm{Q}]=1+K \mathrm{sv}[\mathrm{Q}]$, where $\mathrm{F}_{0}$ and $\mathrm{F}$ are the fluorescence intensities in the absence and presence of a quencher ( $\alpha$-amino phosphonate derivatives), respectively, $K_{\mathrm{q}}$ is the fluorophore quenching rate constant, $K$ sv is the Stern-Volmer quenching constant, $\tau_{0}$ is the lifetime of the fluorophore in the absence of a quencher $\left(\tau_{0}\right.$ $=10^{-8}$ ), and [Q] is the concentration of quencher [47]. The binding constants and the binding sites for the complex formation between $\alpha$-amino phosphonate derivatives and P9-1 proteins were obtained from [48]: $\lg \left(\mathrm{F}_{0}-\mathrm{F}\right) / \mathrm{F}=\lg K_{\mathrm{a}}$ $+\mathrm{n} \lg [\mathrm{Q}]$. Where $\mathrm{K}_{\mathrm{a}}$ is the binding constant and $\mathrm{n}$ is the number of binding sites.
For the ITC analysis, The ITC binding experiments were performed using an ITC 200 Micro Calorimeter (GE Health, USA) at $25^{\circ} \mathrm{C}$. The proteins were dialyzed against a buffer for $24 \mathrm{~h}$ before preparing the SRBSDV P9-1 protein. The buffer contained $10 \mathrm{mM}$ Tris- $\mathrm{HCl}$ and $100 \mathrm{mM}$ sodium chloride $(\mathrm{pH} 7.5)$. The $\alpha$-amino phosphonate derivative ligands were titrated against the SRBSDV P9-1 protein in a $200 \mu \mathrm{L}$ sample cell using a 40 $\mu \mathrm{L}$ microsyringe as follows: $0.4 \mu \mathrm{L}$ for the first injection and $2 \mu \mathrm{L}$ for the next 19 injections at an interval of $150 \mathrm{~s}$. The integrated heat data were analyzed using the one-setof-sites model in MicroCal Origin 7.0, according to the manufacturer's instructions. The first data point was not used in the analysis. The binding parameters, $\Delta \mathrm{H}$ (reaction enthalpy change in cal $/ \mathrm{mol}$ ), $\mathrm{K}$ (binding constant in $\mathrm{mol}^{-1}$ ) and $n$ (number of molecules per SRBSDV P9-1 or mutant) were floated during the fit. The binding free energy $(\Delta \mathrm{G})$ and the reaction entropy $(\Delta \mathrm{S})$ were calculated using the equations, $\Delta \mathrm{G}=-\mathrm{RT} \ln \mathrm{K}(\mathrm{R}=1.9872 \mathrm{cal} / \mathrm{mol} / \mathrm{K}, \mathrm{T}=298$ $\mathrm{K})$ and $\Delta \mathrm{G}=\Delta \mathrm{H}-\mathrm{T} \Delta \mathrm{S}$. The dissociation constant $\mathrm{Kd}$ was calculated as $1 / \mathrm{K}$ [49].

For the MST analysis [50], the binding was calculated for MST Monolith NT. 115 (Nano Temper Technologies, Germany). A range of ligands from 0 $\mu \mathrm{M}$ to $5 \mu \mathrm{M}$ was incubated with $0.5 \mu \mathrm{M}$ of purified recombinant proteins for $5 \mathrm{~min}$ with a NT-647 dye (Nano Temper Technologies, Germany) and was used in the thermophoresis experiment at a final concentration of $20 \mathrm{nM}$. A 16 point dilution series was made for selected compounds in DMSO. Each compound dilution series was subsequently transferred to protein solutions in $10 \mathrm{mM}$ Tris- $\mathrm{HCl}$ and $100 \mathrm{mM}$ sodium chloride $\mathrm{pH} \mathrm{7.5,0.05 \%}$ Tween-20. After a $15 \mathrm{~min}$ incubation of the labeled P9-1 with each dilution point (1:1 mix) at room temperature, samples were filled into standard capillaries (NanoTemper Technologies, Germany). Measurements were taken on a Monolith NT.115 microscale thermophoresis system (NanoTemper Technologies, Germany) under a setting of $20 \%$ LED and $40 \%$ IR laser. Laser on time was set at $30 \mathrm{~s}$, and laser-off time was set at $5 \mathrm{~s}$. The $K d$ values were calculated from the duplicate reads of three separate experiments using the mass action equation in the Nano Temper software.

For the docking experiments analysis, the initial structure of SRBSDV P9-1 was revised by adding lost residues and hydrogen atoms, and by checking bonds and bumps. Subsequently, energy was minimized in the steepest descent calculations and conjugated gradient calculations were undertaken using Discovery studio 4.5 (Accelrys, CA, USA). The optimized geometries were used to construct the whole structures. The final structures were optimized by fixing the macrocycle with a conjugated gradient. Atomic Gasteiger-Huckel charges were assigned to the ligand and receptor. Most of the parameters for the docking calculation were set to the default values recommended by the Discovery studio 
4.5 software. Each docked structure was scored by the built-in scoring function and was clustered by $0.8 \AA$ of RMSD criteria. The docking analysis results were used to determine the electrostatic potential and partial atomic charges by performing electrostatic potential fitting, according to the Merz-Singh-Kollman scheme with the Gaussian-optimized geometries [51].

\section{Abbreviations}

SRBSDV, Southern rice black-streaked dwarf virus; Vps, viroplasms; RBSDV, rice black-streaked dwarf virus; MRCV, Mal de Río Cuarto virus; ss-RNA, singlestranded RNA; VFs, viral factories; ITC, isothermal titration calorimetry; MST, Microscale Thermophoresis; FT, fluorescence titration; IPTG, isopropyl- $\beta$-Dgalactopyranoside; SEC, size exclusion chromatography; RMSD, root mean square deviation; $\mathrm{Kd}$, dissociation constant; NCBI, National Center of Biotechnology Information.

\section{Author contributions}

Prof. B. A. Song and X. Y. Li conceived and designed the experiments. Dr. X. Y. Li performed the experiments. Dr. Y. Ding performed the molecular dynamics simulation. Dr. G. P. Zhang synthesized $\alpha$-amino phosphonate derivatives. Dr. X. Y. Li, Y. Ding, K. Chen and L. Z. Luo analyzed the data. Profs. D. Y. Hu contributed reagents/materials/analysis tools. Profs. B. A. Song and Dr. X. Y. Li wrote and revised the manuscript. All authors have read and approved the final manuscript.

\section{CONFLICTS OF INTEREST}

The authors declare no conflicts of interest.

\section{FUNDING}

This research was supported by a grant of the National Natural Science Foundation of China (Nos. 21732002, 31460460 and 21502032). We thank Dr. X. Y. Zhao at beamline BL17U (Shanghai Synchrotron Radiation Facility, China) for kindly assistance and coordination in data collection; Prof. J. H. Gan (Fudan University) for assistance in data processing. Accession codes: The $2.2 \AA$ crystal structure of SRBSDV P9-1 has been deposited into the RCSB Protein Data Bank under accession code 5EFT.

\section{REFERENCES}

1. Suzuki N, Hosokawa D, Matsuura Y, Kikuchi A, Omura T. In vivo and in vitro phosphorylation of rice dwarf phytoreovirus Pns12 cytoplasmic nonstructural protein. Arch Virol. 1999; 144:1371-1380.
2. Wei T, Kikuchi A, Moriyasu Y, Suzuki N, Shimizu T, Hagiwara K, Chen H, Takahashi M, Ichiki-Uehara T, Omura T. The spread of Rice dwarf virus among cells of its insect vector exploits virus-induced tubular structures. J Virol. 2006; 80:8593-602.

3. Shimizu T, Yoshii M, Wei T, Hirochika H, Omura T. Silencing by RNAi of the gene for Pns12, a viroplasm matrix protein of Rice dwarf virus, results in strong resistance of transgenic rice plants to the virus. Plant Biotechnol J. 2009; 7:24-32.

4. Zhang HM, Yang J, Chen JP, Adams MJ. A black-streaked dwarf disease on rice in China is caused by a novel fijivirus. Arch Virol. 2008; 153:1893-1898.

5. Zhou GH, Wen JJ, Cai DJ, Li P, Xu DL, Zhang SG. Southern rice black-streaked dwarf virus: a new proposed Fijivirus species in the family Reoviridae. Chin Sci Bull. 2008; 53:3677-3685.

6. Wang Z, Yu L, Jin L, Wang W, Zhao Q, Ran L, Li X, Chen Z, Guo R, Wei Y, Yang Z, Liu E, Hu D, Song B. Evaluation of Rice Resistance to Southern Rice Black-Streaked Dwarf Virus and Rice Ragged Stunt Virus through Combined Field Tests, Quantitative Real-Time PCR, and Proteome Analysis. Viruses. 2017; 9:2-7.

7. Wang Z, Yu D, Li X, Zeng M, Chen Z, Bi L, Liu J, Jin L, Hu D, Yang S, Song B. The development and application of a Dot-ELISA assay for diagnosis of southern rice blackstreaked dwarf disease in the field. Viruses. 2012; 4:167-83.

8. Zhou G, Xu D, Xu D, Zhang M. Southern rice blackstreaked dwarf virus: a white-backed planthoppertransmitted fijivirus threatening rice production in Asia. Front Microbiol. 2013; 4:270-279.

9. Wang ZH, Fang SG, Xu JL, Sun LY, Li DW, Yu JL. Sequence analysis of the complete genome of rice black-streaked dwarf virus isolated from maize with rough dwarf disease. Virus Genes. 2003; 27:163-168.

10. Distéfano AJ, Conci LR, Muñoz Hidalgo M, Guzmán FA, Hopp HE, del Vas M. Sequence analysis of genome segments S4 and S8 of Mal de Rio Cuarto virus (MRCV): evidence that the virus should be a separate Fijivirus species. Arch Virol. 2002; 147:1699-1709.

11. Yin X, Xu FF, Zheng FQ, Li XD, Liu BS, Zhang CQ. Molecular characterization of segments S7 to S10 of a southern rice black-streaked dwarf virus isolate from maize in northern China. Virol Sin. 2011; 26:47-53.

12. Mao Q, Zheng S, Han Q, Chen H, Ma Y, Jia D, Chen Q, Wei T. New model for the genesis and maturation of viroplasms induced by fijiviruses in insect vector cells. J Virol. 2013; 87:6819-6828.

13. Wang Q, Yang J, Zhou GH, Zhang HM, Chen JP, Adams MJ. The complete genome sequence of two isolates of southern rice black-streaked dwarf virus, a new member of the genus fijivirus. J Phytopathol. 2010; 158:733-737.

14. Shimizu T, Nakazono-Nagaoka E, Akita F, Uehara-Ichiki T, Omura T, Sasaya T. Immunity to rice black streaked 
dwarf virus, a plant reovirus, can be achieved in rice plants by RNA silencing against the gene for the viroplasm component protein. Virus Res. 2011; 160:400-403.

15. Jia D, Chen H, Zheng A, Chen Q, Liu Q, Xie L, Wu Z, Wei T. Development of an insect vector cell culture and RNA interference system to investigate the functional role of fijivirus replication protein. J Virol. 2012; 86:5800-5807.

16. Li J, Xue J, Zhang HM, Yang J, Lv MF, Xie L, Meng Y, Li PP, Chen JP. Interactions between the P6 and P5-1 proteins of southern rice black-streaked dwarf fijivirus in yeast and plant cells. Arch Virol. 2013; 158:1649-1659.

17. Wang Q, Tao T, Zhang Y, Wu W, Li D, Yu J, Han C. Rice black-streaked dwarf virus P6 self-interacts to form punctate, viroplasm-like structures in the cytoplasm and recruits viroplasm-associated protein P9-1. Virol J. 2011; 8:24-29.

18. Sun L, Xie L, Andika IB, Tan Z, Chen J. Non-structural protein P6 encoded by rice black-streaked dwarf virus is recruited to viral inclusion bodies by binding to the viroplasm matrix protein P9-1. J Gen Virol. 2013; 94:1908-1916.

19. Li J, Xue J, Zhang HM, Yang J, Xie L, Chen JP. Characterization of homologous and heterologous interactions between viroplasm proteins P6 and P9-1 of the fijivirus southern rice black-streaked dwarf virus. Arch Virol. 2015; 160:453-457.

20. Kar AK, Bhattacharya B, Roy P. Bluetongue virus RNA binding protein NS2 is a modulator of viral replication and assembly. BMC Mol Biol. 2007; 8:4.

21. Wei T, Shimizu T, Hagiwara K, Kikuchi A, Moriyasu Y, Suzuki N, Chen H, Omura T. Pns12 protein of rice dwarf virus is essential for formation of viroplasms and nucleation of viral-assembly complexes. J Gen Virol. 2006; 87:429-438.

22. Mohan KV, Muller J, Som I, Atreya CD. The Nand C-terminal regions of rotavirus NSP5 are the critical determinants for the formation of viroplasmlike structures independent of NSP2. J Virol. 2003; 77:12184-12192.

23. Taraporewala Z, Chen D, Patton JT. Multimers formed by the rotavirus nonstructural protein NSP2 bind to RNA and have nucleoside triphosphatase activity. J Virol. 1999; 73:9934-43.

24. Broering TJ, Parker JS, Joyce PL, Kim J, Nibert ML. Mammalian reovirus nonstructural protein microNS forms large inclusions and colocalizes with reovirus microtubule-associated protein micro2 in transfected cells. J Virol. 2002; 76:8285-97.

25. Miller CL, Arnold MM, Broering TJ, Hastings CE, Nibert ML. Localization of mammalian orthoreovirus proteins to cytoplasmic factory-like structures via nonoverlapping regions of $\mu$ NS. J Virol. 2010; 84:867-882.

26. Gillian AL, Nibert ML. Amino terminus of reovirus nonstructural protein sigma NS is important for ssRNA binding and nucleoprotein complex formation. Virology. 1998; 240:1-11.

27. Gillian AL, Schmechel SC, Livny J, Schiff LA, Nibert ML. Reovirus protein $\varsigma N S$ binds in multiple copies to single- stranded RNA and shares properties with single-stranded DNA binding proteins. J Virol. 2000; 74:5939-5948.

28. Akita F, Higashiura A, Shimizu T, Pu Y, Suzuki M, UeharaIchiki T, Sasaya T, Kanamaru S, Arisaka F, Tsukihara T, Nakagawa A, Omura T. Crystallographic analysis reveals octamerization of viroplasm matrix protein P9-1 of rice black streaked dwarf virus. J Virol. 2012; 86:746-756.

29. Zhang C, Liu Y, Liu L, Lou Z, Zhang H, Miao H, Hu X, Pang Y, Qiu B. Rice black streaked dwarf virus P9-1, an alpha-helical protein, self-interacts and forms viroplasms in vivo. J Gen Virol. 2008; 89:1770-1776.

30. Wu J, Li J, Mao X, Wang W, Cheng Z, Zhou Y, Zhou X, Tao X. Viroplasm protein P9-1 of Rice black-streaked dwarf virus preferentially binds to single-stranded RNA in its octamer form, and the central interior structure formed by this octamer constitutes the major RNA binding site. J Virol. 2013; 87:12885-12899.

31. Li X, Zhang W, Ding Y, Wang Z, Wu Z, Yu L, Hu D, Li P, Song B. Characterization of the Importance of Terminal Residues for SRBSDV P9-1 Viroplasm Formations. Pro Exp Pur. 2015; 111:98-104.

32. Li X, Liu J, Yang X, Ding Y, Wu J, Hu D, Song B. Studies of Binding interactions between Dufulin and southern rice black-streaked dwarf virus P9-1. Bioorg Med Chem. 2015; 23:3629-3637.

33. Wang Z, Li X, Wang W, Zhang W, Yu L, Hu D, Song B. Interaction research on the antiviral molecule dufulin targeting on southern rice black streaked dwarf virus p9-1 nonstructural protein. Viruses. 2015; 7:1454-1473.

34. Song BA, Yang S, Jin LH, Bhadury S. Environment friendly anti-plant viral agent. Berlin: Springer; 2009: 234-53.

35. Zhang G, Hao G, Pan J, Zhang J, Hu D, Song B. Asymmetric Synthesis and Bioselective Activities of $\alpha$-Amino-phosphonates Based on the Dufulin Motif. J Agric Food Chem. 2016; 64:4207-13.

36. Zhang W, Li X, Zhang G, Ding Y, Ran L, Luo L, Wu J, Hu D, Song B. Binding interactions between enantiomeric $\alpha$-aminophosphonate derivatives and tobacco mosaic virus coat protein. Int J Biol Macromol. 2017; 94:603-610.

37. Li X, Hao G, Wang Q, Chen Z, Ding Y, Yu L, Hu D, Song B. Ningnanmycin inhibits tobacco mosaic virus virulence by binding directly to its coat protein discs. Oncotarget. 2017; 8:82446-58. https://doi.org/10.18632/oncotarget.19401.

38. Bergfors TE. Protein crystallization. La Jolla: International University Line. 2009; PP. 95-108.

39. Otwinowski Z, Minor W. Processing of X-ray diffraction data collected in oscillation mode. Meth Enzy. 1997; 276:307-326.

40. Collaborative Computational Project, Number 4. The CCP4 suite: programs for protein crystallography. Acta Crystallogr D Biol Crystallogr. 1994; 50:760-763.

41. Read RJ. Pushing the boundaries of molecular replacement with maximum likelihood. Acta Crystallogr D Biol Crystallogr. 2001; 57:1373-1382. 
42. Emsley P, Cowtan K. Coot: model-building tools for molecular graphics. Acta Crystallogr D Biol Crystallogr. 2004; 60:2126-2132.

43. Murshudov GN, Vagin AA, Dodson EJ. Refinement of macromolecular structures by the maximum-likelihood method. Acta Crystallogr D Biol Crystallogr. 1997; 53:240-255.

44. DeLano WL. The PyMOL Molecular Graphics System. 2002.

45. Kleywegt GJ, Brunger AT. Checking your imagination: applications of the free R value. Structure. 1996; 4:897-904.

46. Guo XJ, Li XZ, Jiang YC, Yi L, Wu Q, Chang HC, Diao X, Sun Y, Pan XT, Zhou NN. A spectroscopic study on the interaction between p-nitrophenol and bovine serum albumin. J Lumin. 2014; 149:353-360.

47. Yue Y, Liu J, Liu R, Dong Q, Fan J. Binding of helicid to human serum albumin: a hybrid spectroscopic approach and conformational study. Spectrochim Acta A Mol Biomol Spectrosc. 2014; 124:46-51.
48. Ma XL, Yan J, Wang Q, Wu D, Li H. Spectroscopy study and co-administration effect on the interaction of mycophenolic acid and human serum albumin, Int J Biol Macromol. 2015; 77:280-286.

49. Deng LJ, Peng QL, Wang LH, Xu J, Liu JS, Li YJ, Zhuo ZJ, Bai LL, Hu LP, Chen WM, Ye WC, Zhang DM. Arenobufagin intercalates with DNA leading to G2 cell cycle arrest via ATM/ATR pathway. Oncotarget. 2015; 6:34258-75. https://doi.org/10.18632/oncotarget.5545.

50. Seo EJ, Efferth T. Interaction of antihistaminic drugs with human translationally controlled tumor protein (TCTP) as novel approach for differentiation therapy. Oncotarget. 2016; 7:16818-39. https://doi.org/10.18632/ oncotarget.7605.

51. Okamoto T, Yamada K, Koyano Y, Asada T, Koga N, Nagaoka M. A minimal implementation of the AMBERGAUSSIAN interface for ab initio QM/MM-MD simulation. J Comput Chem. 2011; 32:932-42. 